The Geneva Papers on Risk and Insurance, 22 (No. 84, July 1997) 378-391

\title{
The Service Liberalisation Agenda of the World Trade Organisation What are the Issues?
}

\author{
by Julian Arkell*
}

\section{Globalisation: the challenge}

Advances in science and information technology arise from greater specialisations that fragment subject matters and systems into new polarisations, yet the globalisation such innovations drive is linking previously disparate policy areas and institutions. Trade interfaces reach ever deeper into societal regimes, throwing cultural differences into high relief, with their varying norms and standards, and giving rise to fears of dominance, calls for protectionism, negotiating stances based on direct reciprocity, and attempts to project the extra-territorial reach of national laws. Services trade has now become entangled in a wide web of social issues that clamour to be addressed.

However, the dynamics of globalisation are also leading to autonomous liberalisation, as countries aim to attract investment, and avoid being cut off from business services increasingly demanded by all sectors of the economy to improve efficiency. More governments appreciate that restrictions on foreign enterprises can bring negative effects when indigenous suppliers are unduly cosseted.

Technological innovation in transport and informatic services are creating new business opportunities, greatly facilitated by liberalisation, deregulation and privatisation policies. New economic models seem to prove that technical progress is central to raising economic growth and dependent on investment in human and education and skills. Market friendly policies work best, including a liberal trade regime, secure property rights and contract law, low taxes and low public spending. Modern infrastructure network systems need great amounts of capital, that now have to be attracted from the private sector, since public budgets are reined back tightly.

Treasury Secretary Robert Rubin described the factors that have enabled the US economy to grow consistently faster than the rate most economists calculate is the underlying potential, yet without inflationary consequences. "Over the past decade, US industry has become very much more productive and competitive. This change is the result of a more professional approach to corporate management, an open-minded adoption of new technology, globalisation, and the consequences of corporate restructuring." Perhaps his view is not surprising as Rubin was a banker on Wall Street.

* International Trade and Services Policy. Box 41, Mussupta 2, 07712 San Clemente, Menorca, Spain. 
Management perceptions and practices on how to react to the rapidly evolving business environment appear to have largely converged, derived from a similar conceptual analysis and methodology. Great stress is placed on reducing company activities to core skills, focusing more closely on markets and customer needs, striving for quality inputs and products, and achieving flexible management, and cost reduction. This has led to the extraordinary growth of business services, the intermediate inputs of professional skills, know-how and management before, during and after production processes in all sectors. They have mainly experienced a demand pull from their clients going global. However, not much of the output is traded across borders, and commercial presence is a characteristic of many services, and has changed perceptions of what "obstacles" a trade organisation should tackle. Additionally many services are highly regulated mainly for consumer protection purposes.

As the WTO prepares to celebrate the 50th anniversary of the GATT, how does it measure up to the challenge of globalisation? How is it reacting to the global movement of capital, when with few exceptions, investment is the subject of separate bilateral agreements? Can it facilitate the movement of people who are needed by firms to go abroad to work, but are hindered by stringent immigration regimes?

\section{The WTO response}

\subsection{GATT and the Uruguay Round}

The GATT has long grappled with issues arising from the globalisation of merchandise trade. But it was not until the successful outcome of the Uruguay Round of trade negotiations at the end of 1993 that the WTO was created as a global organisation covering all trade, by the inclusion of services - which of course all along had been the necessary element supporting the international goods business. Many service sectors have their own international organisations and webs of agreements such as those for air and maritime transport, telecommunications, and postal services. Official customs authorities have a world-wide body.

There are of course also other fundamental issues of a global nature which condition WTO responses. These include human rights, military security, health, labour standards, and environmental agreements. At present though, it is only the last that demands a great deal of attention in the WTO, and is proving highly complex to deal with. Some believe the interface with labour standards should be similarly managed, but the first three are specifically removed from the trade body's ambit.

\subsection{The Singapore Ministerial}

The WTO emerged stronger after its first Ministerial meeting held in Singapore in December 1996. The outcome showed that as an institution it has started to face up to the need for further extension of its disciplines to meet the challenges of globalisation.

Following Singapore the WTO looks set to ensure that the growing number of regional trading arrangements will not detract from handling trade multilaterally, that disciplines for trade-related investment laws may have to embrace all aspects of investment, and that competition and trade policies and laws interact so closely that inconsistencies and gaps between them must be dealt with. As to the logistics, so vital to the flow of goods, attention will focus on simplifying trade procedures and customs modernisation, where modern electronic data interchange techniques can sharply reduce delays to transit and the costs of administration. 
Liberalisation for the vast government procurement markets have yet to be truly globalised, but the Uruguay Round took a large step in the right direction, that has now to be followed up with both deepening and widening. Particular problems over corruption are to be dealt with in this context.

\subsection{Dispute settlement}

The WTO dispute settlement system is being put to full use by countries both large and small, which is a good augury. It has been engaged on a variety of hot conflicts, two already involving the GATS disciplines for the distribution sector (between the US and (a) Japan in the Kodak-Fuji case, and (b) the EU in the banana case).

Expert advisory opinions from panellists are needed in each specialist services field, who can describe how the legal language applies to the set of facts, and how the results would operate. There may be a danger for dispute settlement panel deliberations if necessary data are absent, since violations have to be enforced, and retaliation should not be disproportionate to the violation. This is a likely scenario for some years until statistics on services trade and investment become available in the necessary form.

Globalisation has increased the chance of conflict between business and governments, so some are calling for a dispute settlement filter to prevent to rapid escalation of a multiplicity of cases to the government to government level.

Some commercial matters have been newly brought under WTO disciplines such as IPR rights, though specific action is pushed back to national courts. Integration of investment and competition rules raises the prospect of more. The WTO may not be very effective in this area since there are no private rights of action at the WTO, nor any such prospect in the near future.

Seasoned negotiators probably still think that occasional unilateralism can bring pressure to redress imbalances when used judiciously and sparingly, and should not be consigned to totally unqualified opprobrium.

\subsection{Structural changes}

Clearly it was a remarkable achievement to bring the WTO into being. However, inserting new fundamental dimensions into its structure will not be easy, nor will it be simple to extend its competence. There are checks and balances in its charter, due to the need for consensus on new initiatives. Introducing new chapters for environmental, investment and competition regimes will need full consensus, as would other new Codes, which could lead to gridlock.

Nevertheless, the present gaps in obligations on investment, and competition disciplines call for architectural reform of the international policy framework. The multilateral rules should be better integrated and less segmented. Business sees trade and investment as inseparable, and would like no conceptual and institutional differences for the multilateral disciplines. Government restrictions on competition have to be repealed, and complementary disciplines for private sector activities co-operatively enforced to underpin fair markets.

Possibly this might mean divesting the GATS of its investment aspects to remove the distinction between goods and services. The same is probably necessary for rules on people moving between countries as part of cross-border trade. People are of central importance to deeper economic integration, and the movement of skilled and professional workers will have to be treated more favourably. 
How would this be negotiated?There could be another big Round with overall reciprocity: the WTO comparative advantage is its integrated approach, embracing all traded sectors and the issues arising. Some point out that the big rounds will not come around fast enough: where governments face major structural changes to their economies, adjustments for sectors have to form part of big packages so that politicians can sell them to their constituents. This may take many years to prepare and put together.

There could be negotiations in regional groupings, which also holds dangers, or a sectional approach adding more Codes to the WTO Annex 4, for new plurilateral regimes. However, there could be dangers if non-MFN agreements are imposed onto the WTO structure. It seems that liberalisation is more difficult to achieve where there are big disparities in market opening, as evidenced by the negotiations on financial services and basic telecommunications. Also the sectoral reciprocity mode presents fewer possible bargains, especially if some markets are already open.

Those with an already open services market point out that concessions can be made only once, and yet governments with relatively closed regimes seldom bind a position as high as their current laws actually have allowed. Where a sector is unbound, governments could in future force firms out, whilst still obtaining the full benefits of the WTO. This is why some MFN leverage is being retained to deploy in later negotiations.

Pressure on the WTO to do something on investment is growing due to the imminent creation of the Multilateral Agreement on Investment (MAI) by OECD members. The MAI is designed to establish a broad multilateral framework of international investment with high standards for the liberalisation of investment regimes and investment protection, with effective dispute settlement procedures. It will be a free-standing international treaty open to all OECD members, and to accession by non-Member countries. The negotiations are to be concluded in December 1997. It will include disciplines on performance requirements, privatisation, state-owned enterprises, monopolies and concessions, corporate practices and key personnel. It is intended to stimulate a move within the WTO towards universal agreement, but it showed signs of producing a negative backlash from countries that have had no say in its formation.

\subsection{Standards}

Standards are met across the whole spectrum of WTO business, and the issue is a systemic one of growing importance. For instance, frictions arise from differing standards for goods products, production and process methods, environmental laws, workers' rights, competition policies, investment conditions, subsidies and other state aids, and taxation.

In some areas the mutual recognition of standards and conformity assessment procedures have been developed, as it has been for professional qualifications. The WTO will not itself set standards, and it will have to develop a dynamic relationship with standard setting bodies, and mutual recognition processes, so that the many interfaces with trade can be satisfactorily managed.

\subsection{Developing countries}

What is on offer for developing countries in next Round? To many, the new issues appear as a one-sided agenda, fearing as they do that their firms may be wiped out by international competitors, and they want time to build strength to compete on their own home 
markets, as well as abroad later on. Such countries are unlikely candidates to gain advantage from free-riding. They will seek to make links between the new issues and completion of tariff reductions and other adjustments in agriculture and textiles.

\subsection{Daunting workload}

The workload now in train at the WTO is very heavy, and much has to be accomplished before the next GATS round of negotiations. There are also the accession negotiations for China, Russia and many others. This adds up to a daunting prospect, and probably beyond the capacity of most WTO members to handle. Extra human resources with the right experience will have to be drafted into the process for it to succeed, including for the WTO Secretariat.

\section{GATS: framework development}

The evident "architectural defects" of the GATS have been criticised, and business does not find the schedules of specific commitments user friendly. But many negotiators think it will stand the test of time, as it maintains a balance between achieving some liberalisation, and protection for weaker countries that feared western dominance. It was doubtful, given the negotiating objectives, that the framework could have been different. Since services delivery involve the movement of the factors of production, the innovative modes of delivery approach was created to catch measures, and an artificial means of characterising entry by foreigners into markets was erected, since many countries were so nervous. Officials excuse the framework's complexity and the small degree of liberalisation and standstill achieved, as reflecting insufficient time available for negotiations.

The GATS negotiations showed that an overall balance of benefits could produce a better result than relying solely on sectoral work outs. Many had hoped that all MFN exemptions would be time limited, and it was a failure of negotiations that they were not. The US had to accept the concept of progressivity of liberalisation, but if some open markets are bound whilst others can be kept shut, MFN exemptions for reciprocity have to be the battleground.

Suggestions abound for how to take effective new steps for further liberalisation, and include:

- chipping away at the MFN exemptions

- increasing the sector coverage of specific commitments

- reducing the limitations on market access and national treatment

- making additional commitments, such as of the competition policy type, and

- closing the gap between specific commitments and policies actually applied.

As to the architectural reform of the GATS framework, suggestions include:

- a move from positive to negative listing of commitments to make the regulatory position more transparent

- more general obligations in the framework, such as for domestic regulations

- market access to be solely price-based, to get rid of quantitative restrictions

- national treatment as a general obligation, and

- market access and national treatment explicitly separated, so that national treatment deals with all discriminatory measures, with none being left in market access. 
Some see the GATS as a model for extending the multilateral system into new areas because it disciplines factor flows, data flows, and the recognition of standards and qualifications.

\subsection{Safeguards (Article $X$ )}

Negotiations on safeguard measures have to be completed by 31 December 1997. In order to encourage developing countries to make more liberalisation commitments, some emergency safeguards rules are probably needed. This is conceptually difficult due to the interplay of the four modes of delivery, and how to cater for the tests of injury, causality and origin of invisible services, and compounded by the lack of statistics on such matters. It seems unlikely that for OECD members GATS sanctioned actions would be compatible with their mutual obligations.

Also in practice services are less likely to suffer from import surges, because their characteristics frequently include:

- economies of scope rather than scale (not many services are made in one production unit in one country for delivery at the retail level in many countries, as is done for eg. cars and computers)

- high entry costs (such as for the infrastructure sectors)

- delivery through commercial presence rather than cross-border

- high degrees of regulation

- imperfect competition

- asymmetry of information

- price inelasticity for experience and credence supplies

- a preponderance of SMEs

- few sunset services sectors

European business has urged that any Article $\mathrm{X}$ language should provide for only a limited scope, such as in circumstances of an exceptional and non-recurrent nature and on a strictly temporary basis, so as to minimise the potentially trade restrictive effects. It should be subject to proper notification and control, notably by means of the dispute settlement mechanism. How safeguards apply to the commercial presence and movement of persons modes of supply should be carefully considered. It is important to prevent abuse, and due to the widely varying specific characteristics of services sectors, each will need detailed consideration.

\subsection{Subsidies (Article XV)}

For goods there is a highly developed regime of disciplines on subsidies: some are prohibited (eg. for exports), some acceptable, but most actionable, with provision for countervailing duties to redress unfair distortions. Similarly, GATS disciplines are needed on subsidies, for which there should be no carve out. They should be scheduled, and should not be discriminatory where there are no national treatment limitations. A countervailing mechanism may also be needed, and there should be a ban on cross-subsidisation so as to meet fair competition precepts. Situations where there are specific commitments in one mode that is unsubsidised, yet there are subsidies in another connected mode that is not bound, will have to be tackled. 


\subsection{Monopolies (Article VIII) and restrictive business practices (Article IX)}

Especially difficult for the GATS to deal with are situations where there are artificial and heavily regulated monopolies (eg. for air transport and telecoms) and natural monopolies (eg. the utilities), that produce intermediate inputs important for manufacturers and services suppliers alike, because the MFN and transparency disciplines do not produce enough leverage for liberalisation.

Only a minority of WTO members have competition regimes, and these laws do not in principle distinguish goods from services, even if some of the latter benefit from exemptions, and it would seem best for this approach to prevail at the WTO. However, given the substantive differences in laws and procedures, and the fact that most WTO members have not legislated in this area, any negotiations look set to last a long time.

\subsection{Domestic Regulation (Article VI) and Recognition (Article VII)}

All domestic regulations that are GATS consistent but unduly burdensome or trade restrictive, have to be tackled. These are non-discriminatory measures resulting in trade distortion or market access barriers. An assessment of legal systems will form part of the work so that disciplines can be developed. The Article VI.4 language is opaque and yet strict in not allowing any discrimination, so rules will have to be given more specificity as otherwise panels will not have enough guidance to work on. The schedules of specific commitments do not aid transparency. More weight will have to be placed on the Article III Enquiry Points, and regular reports of the Trade Policy Review Mechanism.

The work programme is set to tackle problems with qualification requirements, technical standard, and licensing requirements that arise from differences in levels and methods of regulation. Harmonisation cannot be attempted generally, as might be possible to some degree for Professional Services, but as national treatment is a necessary condition but often not a sufficient one for liberalisation, some minimum harmonisation and mutual recognition cannot be side-stepped.

Some ask how the boundary between national treatment and Article VI.4 disciplines can be drawn, and how regulations can be proved equivalent. This calls for regulatory co-operation, and acceptance of the principle of proportionality.

Sectoral negotiations can be prone to capture by the producers, or the bureaucrats responsible for these sectors who have their turf to protect. Stronger affirmation of the interests of users will be necessary, but as to consumer protection, the GATS makes exceptions for all the main aspects.

\subsection{The movement of natural persons}

Taking the commitments on the movement of people any further will run into the problem of the conceptual parallels between flows of different factors of production: should the same liberalisation rules apply both to the mobility of capital and people despite the evident differences in their impact on society? Dealing with this effectively will demand considerable adjustments in perceptions and processes to enable progress to be made.

Even where there is a binding of temporary access for business persons, problems can arise since not all immigration officials are aware of the dispensations agreed. To avoid professionals being turned back at the border, a hot line to a well versed superior may have to be the norm. 


\subsection{Developing countries}

Any strengthening of the GATT framework must go hand in hand with addressing developing countries' problems. For the governments of smaller, less advanced, economies their utilities, telecoms and financial services are considered key sectors offering strategic instruments in the conduct of their national economic policies. They must see that the great benefits of being accorded MFN treatment by countries with large imports, deserves a response through making some binding commitments themselves that in practice will be at little or no cost.

Negotiations on the removal of non-tariff barriers should translate into commercially relevant changes by developing countries, properly implemented by appropriate officials. Technical assistance programmes to developing countries must help ensure their GATS obligations are implemented.

\subsection{Scheduling problems}

Due to the complex way services are delivered, the rather artificial and cumbersome GATS scheduling method was found necessary. The mechanism is aimed primarily at defining legal commitments, not at transparency, and does not describe the regulatory regime and trade policies. The resulting inherent obscurity of schedules makes it difficult for business to interpret them. An interface is needed to make them more user-friendly.

This is the province of the Committee on Specific Commitments. One way forward might be for the schedules to show all relevant regulations, with those bound being "coloured". Some call for an impact statement to be filed with each specific commitment, so that business can understand its significance in the given regulatory setting. Business looks for legal certainty on which to base investment decisions. The GATS does not contain a definition of each service, and the UN's provisional "Central Product Classification" was used as a guide, which is difficult to apply, and may anyhow be changed, which in turn could affect specific commitments. In financial services and maritime transport it was superseded.

Perhaps an Internet site should be set up by the WTO where queries on regulations could be posted, answered and monitored by trade officials, increasing the amount of information they could react to. The European Commission has set up a home page for public use, where existing commitments of many countries can be examined and comments left about their implementation in practice (http://mkaccdb.eu.int). UNCTAD has started to build up a database of relevant regulations, and perhaps it should add in all de facto barriers, and allow private companies to use it too?

\section{GATS: liberalisation routes}

\subsection{The Working Party on Professional Services}

The Working Party on Professional Services is looking first at domestic regulations affecting accountants, and the hope is that their findings may hold much of relevance to all the professions. Accountants point out that where the professions are also regulators, they are bound by WTO rules, and therefore they should participate in the debate as players, so that their expertise can be harnessed to the process. 
The accountants see that full harmonisation is not realistic, and that they have to accept a multiplicity of regimes with different interests specifically dealt with through private regulation and state backing for international standard setting organisations. They want the WTO to support the profession's international standards developed by the International Federation of Accounting, the International Accountants Standards Council, and the International Organisation of Securities Comissions regulating stock exchanges. Also needed is a competition policy to deal with both state and private practices, and an investment code, because they say that the commercial presence commitments (in Mode 3) do not work at present for them.

The accountants feel that mutual recognition guidelines would be a good thing, but they should be voluntary and not binding, and suggest that any guidelines should deal with such matters as:

- controls on ownership

- types of incorporation and juridical entity

- the composition of boards of directors or partners

- the scope of activities

- types of diploma

- nature of insurance cover

- recognition of qualifications

- nature and duration of licences

- financial and personal liability for errors

- tax, social security, and other public interest regulations.

Soon it will be the turn of the engineers, architects and lawyers to present their views. They will need to work hard to emulate the well organised lobbying performance of the accountants. The International Union of Architects is taking a more proactive stance, and that the International Federation of Consulting Engineers is sending out clear messages. But there is no equivalent for projecting lawyers' views.

OECD has been working since 1994 at identifying barriers to the internationalisation of professional services. It is reviewing national requirements that constitute the principal obstacles, and considering recommendations on less burdensome ways to regulate that do not compromise public or consumer interests, nor unnecessarily impede domestic and international competition. Its excellent studies will inform the GATS process.

\subsection{Telecommunications: achievement}

\subsubsection{Value added services}

Commitments on "value added" services were successfully negotiated and inscribed in the schedules of 48 countries of the GATS in 1993. Most were for electronic and voice mail, on-line data interchange and processing, enhanced fax, and code/protocol conversions. A few went further to include voice and mobile telephone, fax, telex, videotext and data transmission from the "basic" services category.

\subsubsection{Basic telecommunications services}

On 15 February 1997, 69 government agreed to liberalise their markets for telecoms services, though some will phase this in up to 2005 . Others have said they may join the pact during 
1997. The specific commitments will be inscribed in a "fourth protocol" eventually to be part of the GATS. It is open until the end of November for more to sign on, and is due to enter into force on 1 January 1998.

Privatisation and deregulation in many countries has already brought competition from newly licensed operators of fixed and mobile phones, cable TV, and by the use of call cards and call back services. Foreign telecoms operators will be able to own stakes in domestic companies and establish subsidiaries, and will be required to abide by fair competition principles. They can deliver services by any means - copper wire, coaxial or fibre-optic cable, and terrestrial or satellite radio - and build their own, or lease, facilities to compete with local operators, and their own lines so as not to pay fees to local firms for incoming international calls.

\subsubsection{The annex on access to telecoms networks}

Access to telecoms networks for trade is essential, and an Annex on Telecommunications was included in the GATS. This sets out rules governing measures affecting the use of public telecoms "transport networks and services": it excludes TV programming carried by cable or broadcast by radio. Free movement of information must be allowed, including intra-corporate communications, and access to databases. But users are not entitled to services which a telecoms operator does not offer to the public, and it does not mention pricing. Technical co-operation, and international standards for global compatibility and interoperability are encouraged, and the role of the International Telecommunication Union and the International Standard Organisation recognised.

The Annex addresses access to these services by users rather than their ability to enter markets to sell such services. The obligations were crafted to strike a fragile balance between the needs of users for fair terms of access and the needs of the regulators and public telecommunications operators to maintain a system that works and that meets public service objectives.

\subsubsection{The competition "Reference Paper"}

To assure fair competition ensues liberalisation a "Reference Paper" on a telecoms regulatory framework was negotiated. Agreed in April 1996, it consists of a set of principles covering such matters as competition safeguards, interconnection guarantees, transparent licensing processes, and the independence of regulators. It includes language on pricing, such as "cost-oriented rates" and connection "charges that reflect the cost", and it bans "anti-competitive cross-subsidisation". A broad majority of signatories have inserted commitments on these lines, and thus for the first time governments have rendered themselves liable to multilateral dispute settlement on substantive and procedural aspects of competition policy.

\subsubsection{MFN exception}

The US took new MFN exemptions in February 1997 for certain radio andTVbroadcasting techniques, so as to be able to discriminate between foreigners. The EU thinks these constitute a retrospective attempt to withdraw commitments already settled in the broadcasting part of the audio-visual schedules, despite the distinction between telecoms and broadcasting having been resolved much earlier. Some other countries also took exemptions for broadcasting. 


\subsubsection{Liberalisation will take time}

It was a major achievement to conclude negotiations over the whole range of telecoms services. However, this is only the start of a long liberalisation process. Regulators will have to work very hard to help new entrants get started, to challenge the incumbent monopolists be delving into their accounting practices, to mediate between competitors, and to protect consumers adequately without stifling new developments.

\subsubsection{The International Telecomunication Union (ITU)}

The ITU is the oldest universal organisation, and has great powers to allocate uses of the magnetic spectrum and frequency slots for orbiting satellites. Thus the WTO holds only half the key. The accounting rate between countries on international connections is a central ITU feature, and when PTTs are privatised such contracts still form part of the pricing structure. The WTO deals with the right of entry, but not the right to price.

\subsubsection{Single sector negotiations}

Some argue that the completion of the agreement on "basic" telecoms has helped to strengthen the multilateral system by showing that the WTO can successfully forge international pacts, even in complex and difficult sectors, without a comprehensive and lengthy trade round. However, these negotiations took longer than the Uruguay Round they originally formed part of, and the sector's characteristics are not the same as those of professional and financial services for which negotiations also continue. As for the maritime and air transport sectors, no action is planned on liberalisation steps until the next major round of services negotiations begins in the year 2000 .

\subsubsection{Regulating electronic commerce and the Internet}

Because of the standard WTO "exceptions" language, issue of vital concern to electronic commerce, such as security of information and payments, privacy, decency, advertising, fraud, liability for faulty products, and dispute resolution, fall outside the scope of GATS disciplines. These issues are of great interest to the 50 million users of the Internet.

OECD members look set to approve new guidelines on the use of cryptography in electronic commerce. Although not legally binding they are likely to be the basis for national legislation designed to allow continued liberalisation of IT without jeopardising law enforcement. Issues covered include protection of privacy and personal data, lawful access, liability, as well as encryption development and standards.

\subsubsection{Note on the Information Technology Agreement (ITA)}

Separately from the telecoms negotiations, 39 countries signed the ITA on 26 March 1997 to eliminate tariffs on almost all IT products by the year 2000 , in four equal instalments beginning in July 1998, though some developing countries will take until 2005. This is a global market of $\$ 600$ billion. Not only computers, telecoms equipment, semiconductors and scientific instruments are covered, but also software on discs and CD-ROMs for most purposes (other than games), which are covered by GATS.

\subsection{Financial services: hard bargaining}

At the end of the Uruguay Round the impasse in the financial services negotiations nearly caused disaster, because the strong US lobby feared large potential markets would be permitted to maintain existing barriers keeping their firms out, whilst the US market would 
be locked relatively open. The use by the US of the S 301 weapon would be prohibited against WTO members, and no leverage would remain in their hands to prize open closed markets. They would be faced with a free-rider problem without end.

To retain their negotiating coin they took a broad MFN Exemption for the whole sector, which would allow them to discriminate in future in favour of selected countries, though they cannot make things more restrictive for WTO members. However, there is no US legislation pending to give effect to better treatment for any country, and existing laws give full national treatment to established firms.

Last year a wide group of companies in the financial services field in the EU and US formed the Financial Services Leaders Group to work together and form a common view on what they would like to see come out of the financial services negotiations. They want a deal to be concluded by the end of 1997, and urge more countries to come up with offers, to add to those left on the table in 1995. Commitments should respect the GATS precept of progressive liberalisation, and reflect the following goals:

- the right to establish and operate competitively

- access to markets to be the same for foreigners as for local firms

- the removal of cross-border restrictions (apart from those necessary for prudential purposes)

- the reduction of restrictions on the posting of key personnel

- a guarantee that existing investments will not be revoked, and that

- no new restrictions will be created.

Negotiations were reopened in April 1997, and for 60 days after 1 November new commitments and MFN Exemptions can be entered, and existing ones changed or withdrawn. Many countries - especially those with large potential will have to come up with much better offers than those of 1995 , for the US position to move. Otherwise a new scenario may evolve wherein MFN Exemptions treat sets of countries in different tiers.

\subsection{Maritime transport: future negotiations}

\subsubsection{Publicly owned providers}

In the telecoms negotiations it was found easier to liberalise the newer value added services accounting for $20 \%$ of the market, than basic telecoms services provided mostly by publicly owned network operators, including the lucrative international and business calls markets, making up the other $80 \%$.

In the maritime sector the commercial picture is entirely different: $80 \%$ of world trade by volume consists of bulk cargo, and for this there is intense competition. The ships operate between privately owned specialised terminals and the ships can themselves be highly specialised, and the round-the-clock services are not made available to third parties. The focus of the maritime negotiations was therefore on the $20 \%$ of trade consisting of the carriage of intermediate and finished goods - mostly by private shipping companies that sail according set schedules and charge published rates: the liner trade.

Negotiations on maritime services failed despite being extended beyond the end of the Uruguay Round, and will not be reopened until the next GATS round starting in 2000. Vigorous and prolonged efforts were made to build a "critical mass" of countries prepared to do 
away with anti-competitive practices made insufficient headway. These are found in cargo carrying itself, in the mostly publicly owned ports, and in the various other supporting services, many also publicly owned, that enable goods to be collected from manufacturers and delivered right through to customers' premises.

\subsubsection{The liner trade: access to port and auxiliary services}

Little of the liner trade consists of passenger traffic, which nowadays consists mostly of charter holiday cruises and short ferry crossings. An important part involves containers where international competition is enormous between multi-modal operators that own or lease ships and road and rail trucks, to provide integrated door to door services. For these services to be viable not only must ships be permitted to enter national waters, but access on competitive terms is needed to ports and to other auxiliary land-based services.

Ports provide anchorage and berthing, and also pilotage, towing, fuelling, refuse disposal, navigation aids, utilities and emergency repairs. Auxiliary services include cargo handling, storage and warehousing, container stations and depots, agency and freight forwarding, and customs clearance.

The interests of the mostly privately owned international shipping companies were pitted against those of public authorities providing vital port services and often many of the auxiliary ones too. Here monopolistic closure and other restrictive practices abound, often supported by strong unions. Private firms plying the cargo routes are also subjected to anticompetitive practices or collude amongst themselves. The so-called cargo sharing "liner conferences" allocate the trade between any two countries to firms according to ratios set under agreements that also control prices and sailing schedules.

Carriage round the coast between national ports ("cabotage") was not the subject of negotiations, even though for some continental-sized countries its volume is high and competition would lower charges. Taboos here include subsidies for ship construction and operation, and professed national security interests.

\subsubsection{The dynamics of negotiating access}

The next set of negotiations will have to use the leverage of binding the cross-border supply of the competitive $80 \%$ of bulk and container traffic trade, against (a) for the port services - binding market access and national treatment (i.e. in Mode 2), and (b) for auxiliary services, again Mode 2, but also binding commercial presence (Mode 3), and entry for natural persons (Mode 4).

Many firms in the liner trade wish to provide such services themselves, or use private sector providers, whether for logistical services - including inland transport - or administrative services such as freight forwarding, agency and customs clearance. The US will again strongly attack liner conferences that are closed to new entrants, and that set prices and sailing schedules behind closed doors.

\section{Services statistics: the need for improvement}

It is paradoxical that whereas theories in the fields of economics, trade and management seem to be arising that explain current trends, the ability to measure economic activity has been progressively getting worse due to the onset of the services and information era. 
As The Economist wrote recently: "traditional measures of economic performance are becoming increasingly dodgy", and "many of the numbers are wrong", and this has wide implications for macro-economic decisions by governments that are based on them.

There is an urgent need to improve the collection and analysis of data on the services sector, and the need for co-operation between national statistics offices and private sector experts. Some warn that such data gathering should be regulated to prevent undue secrecy, abuse and distortions, since citizens have a right to know. There is also the problem of whether it is appropriate for governments to sell the data they collect under compulsion.

The first chairman of the Council on Trade in Services called for a committee on services statistics to be set up under this council, which should be given support. Ways of assessing the outcome of future services negotiations have to be found. The WTO has very limited statistical capacity. The private sector must work with governments to give a higher priority to services from the smaller pie.

\section{Private sector involvement}

A Deputy Secretary-General of the WTO has made it clear that the WTO process needs private sector input - for the dispute settlement structure, for filling in the framework gaps, and for the negotiations to achieve further liberalisation.

At present the problem is the lack of private sector interest in services trade policy following the conclusion of the Uruguay Round. Activists will have to keep things moving during this period, since business has enormous interests at stake in WTO. It is vital that sector specialists stay involved until the return of renewed general support.

The private sector must also push EU governments to suppress turf fights over competence so as to find one voice for making bold proposals, and prod Japan out of its silence. UNICE is sure that business needs to project its voice from well organised structures to be effective, and at present there is a weakness on the services side. This calls for proper funding for someone to maintain continuity and a professional interface with changing officialdom, as well as developing innovative approaches for solutions to negotiating problems.

Perhaps EU Commision President Santer should take a leaf out of the US trade advisory committee book, and invite a few services CEOs to act officially as interlocutors in the development of services trade policy.

UNCTAD welcomes the input of business to their deliberations related to the new found co-operative stance between the WTO and UNCTAD aimed at preventing duplication. Some Coalitions of Services Industries are already assisting UNCTAD with their programme of supporting the formation of new CSIs in developing countries. 